\title{
The Heart Rates of the Third-Grade Elementary School Students During Physical Education Classes
}

\author{
Ricky Wibowo*, Didin Budiman, Gano Sumarno \\ Physical Education Elementary \\ Universitas Pendidikan Indonesia \\ Kota Bandung, Indonesia \\ *ricky_wibowo@upi.edu
}

\begin{abstract}
The results of research in various countries show that students do not reach the recommended intensity of physical activity during physical education classes. The purpose of this study was to investigate the intensity of physical activity of elementary school students in physical education classes. The study used descriptive quantitative analysis, while the samples of this study were 23 third grade elementary school students (13 males \& 10 females). The tool used to determine the level of physical activity was the heart rate monitor (Polar H10) that was used during the Physical education activities in the physical education teaching program. The results showed that the intensity of physical activity during physical education classes did not reach the recommended intensity of physical activity $(31,20 \%)$ or students totally engaged in active learning time under 50\% MVPA.
\end{abstract}

\section{Keywords: physical activity level, physical education}

\section{INTRODUCTION}

Recently, news related to acute obesity suffered by Sunarti, a mother from Karawang, city of West Java. Sunarti was declared dead shortly after receiving medical treatment at one of the Government Hospitals in the City of Bandung. The obesity case is an example of a number of obesity cases in Indonesia. Based on data, obese people aged $>18$ years over a period of five years, continues to increase gradually [1]. In 2003 the obesity rate reached $10.5 \%$, in 2013 it reached $14.8 \%$ or an increase of $4.3 \%$. However, the rate of obesity in 2018 has increased significantly to $21.8 \%$ or up $7 \%$ from 2013 . If calculated an annual increase from 2013 to 2018 there is a $1.4 \%$ increase in the incidence of obesity per year [1]. This requires serious attention from educators, especially physical education teachers who have a strategic role in promoting health.

Physical education in schools is believed to be a strategic way to promote physical activity for children and adolescents. Quality physical education can make an important contribution to health [2]. Children at elementary school usually have active characteristics, but often children do not get the recommended level of physical activity during class. Based on the results of the review, recommends school-age children participate in physical activities five times a week for 60 minutes in each of their activities [3]. The recommended intensity is around 40-
59\% heart rate reserve (HRR) as known as Moderate to Vigorous Physical Activity (MVPA).

Getting used to regular physical activity at childhood is believed to be one of the key stages in creating an active lifestyle in adulthood [4]. With regular physical activity can reduce the risk of cardiovascular and metabolic diseases in adulthood [5,6]. In Indonesia, recently on January 31, 2019 the Ministry of Health of Indonesia launched recommendations for physical activities at and after of school. Recommended physical activity at school including carrying out physical or sports activities together for 30 minutes every day before class; optimize break time by playing jump rope, etc. While the recommendation after school hours is to do physical activity with moderate to high intensity of at least 60 minutes (accumulative) per day [7].

Regarding the level of physical activity or intensity during physical education lessons, it is recommended that at least $50 \%$ be the intensity of MVPA in an effort to improve cardiovascular fitness [5,8-12]. From these studies it is necessary to be taken seriously by physical education teachers to present appropriate and needed teaching materials according to the level of their development.

To determine the level of physical activity of children when learning takes place, the heart rate monitor is a tool commonly used by researchers and has been tested for its validity and reliability [13,14]. Heart rate monitors are also good at evaluating MVPA [5]. Based on a literature review from previous research, there are several studies that are very relevant. Among the results of the study by Wang et al (2004) which showed only $30 \%$ of total physical education learning included the intensity of MVPA in adolescents aged 13-14 years. Identical with Wang, other study also reported an average time of MVPA intensity of only around $21.62 \pm$ $14.33 \%$ of the total study time [15]. While the results of other studies show that Physical Education learning that takes place has an intensity of MVPA above $50 \%$ of the total Physical Education learning $[10,11,13,16,17]$.

From the previous studies, it's clear that the need to investigate the intensity of physical activity during physical education class, especially in elementary schools. By investigating the intensity of the MVPA it is expected to be able to provide recommendations for physical education 
teachers in preparing the appropriate learning planning design and needed by students. Based on the discussions, the purpose of this study is to investigate the intensity of the MVPA during the learning process.

\section{METHOD}

\section{A. Participant and Setting}

This descriptive study was conducted in the west of Indonesia, precisely in the city of Bandung. Lab School UPI has been selected because it is expected to be able to represent elementary schools in Indonesia, although in small scale and have qualified teacher. A total 23 3rd grade elementary school student. (13 boys and 10 girl); 8-9 years old were joined into study. To represent physical education material at elementary school, locomotor lesson was has chosen to investigate. based on direct observations and medical history checks with the teacher, it was found that the students selected were in good health condition and had no physical disabilities and were able to carry out physical activities during PE lessons.

\section{B. Measurement}

To monitor physical activity is using a heart rate (HR) monitor. From previous studies measure physical activity by demonstrating overall class time pressure with moderate to vigorous physical activity (MVPA) [8-10]. To measure the intensity of physical activity during physical education learning using Polar H10 connected to IPAD Mini 3. Polar is attached to the chest of students. For the installation assisted by technicians from the laboratory of sports and health education faculties and for female students assisted by female teachers at the school. HR monitors are installed just before students begin physical education lessons. the equipment is installed as comfortable as possible with students and given a brief explanation related to the tool so that children feel calm and comfortable when physical activity. The duration of time taken when physical education class takes place is around 40 minutes. This study only retrieves data when students enter the main activity of learning to reduce interference variables.

\section{Analysis}

All data were analysed as descriptive characteristics of the participants are presented as mean \pm SD. We take only two categories of activity. It is MVPA dan non-MVPA. We also present average heart rate, maximum heart rate dan energy expenditure.

\section{RESULT}

Physical education activities at the time the data was taken were locomotor teaching material content in accordance with the syllabus used by the teacher. The characteristic of sample in Labschool elementary, Indonesia University of Education as evaluate in this study are displayed in table 1, respectively. Table 2 show physical activity intensity of student as assessed in this study. The data take from polar team application that attached on iPad mini 3. From the application displayed, we just taken the MVPA each student. According to table 2, the percentage of MVPA for boys reach $32,65 \%$ greater than girl that attain $31,08 \%$. It shows that boys have greater intensity during physical education activities than girl. While the percentage of students who reach MVPA 50\% is 10 percent of the total male students or only one boy. No different with the boys, the girls are also only one person who achieved MVPA $50 \%$ or 16 percent. Tottaly,3rd grade elementary school student the students at labschool UPI attain $31,20 \%$ MVPA or not reaching as recommended MVPA at doing activity in PE classes.

TABLE I. SAMPLE CHARACTERISTIC

\begin{tabular}{|c|c|c|c|c|c|}
\hline \multirow{2}{*}{ No } & \multirow{2}{*}{ Gender } & \multirow{2}{*}{ Height (cm) } & \multirow{2}{*}{ Weight (kg) } & \multicolumn{2}{|c|}{ Age } \\
\cline { 5 - 6 } & & & years & month \\
\hline 1 & B & 132 & 39 & 8 & 2 \\
\hline 2 & B & 122,5 & 23 & 8 & 2 \\
\hline 3 & B & 134,5 & 40 & 8 & 5 \\
\hline 4 & G & 124 & 29 & 8 & 5 \\
\hline 5 & G & 124 & 24 & 9 & 1 \\
\hline 6 & B & 134 & 31 & 9 & 2 \\
\hline 7 & B & 124 & 24 & 9 & 2 \\
\hline 8 & G & 134 & 38 & 7 & 11 \\
\hline 9 & B & 136 & 28 & 8 & 8 \\
\hline 10 & G & 132 & 30 & 8 & 8 \\
\hline 11 & G & 123,5 & 24 & 9 & 1 \\
\hline 12 & G & 127 & 25 & 8 & 6 \\
\hline 13 & G & 124 & 25 & 8 & 5 \\
\hline 14 & B & 120 & 21 & 9 & 2 \\
\hline 15 & G & 128,5 & 33 & 9 & 2 \\
\hline 16 & G & 126 & 33 & 8 & 5 \\
\hline 17 & B & 132 & 26 & 8 & 4 \\
\hline 18 & B & 127 & 20 & 9 & 1 \\
\hline 19 & B & 130 & 43 & 8 & 7 \\
\hline 20 & B & 124 & 27 & 8 & 4 \\
\hline 21 & G & 134 & 30 & 9 & 1 \\
\hline 22 & B & 128 & 45 & 8 & 4 \\
\hline 23 & B & 120 & 20 & 8 & 3 \\
\hline
\end{tabular}

TABLE II. MEAN \% MVPA AND PERCENTAGE OF STUDENTS REACH 50\% MVPA DURING PHYSICAL EDUCATION ( $\mathrm{N}=23$ ).

\begin{tabular}{|c|l|l|l|l|l|}
\hline Sex & $\begin{array}{c}\text { Total } \\
\text { (N=23) }\end{array}$ & $\begin{array}{c}\text { Mean } \\
\text { \% } \\
\text { MVPA }\end{array}$ & $\begin{array}{c}\text { SD } \\
\text { MVPA }\end{array}$ & $\begin{array}{c}\text { Time } \\
\text { MVPA } \\
\text { (minutes) }\end{array}$ & $\begin{array}{c}\text { Percentage } \\
\text { sample } \\
\text { reach 50\% }\end{array}$ \\
\hline Boys & 13 & 32,65 & 1,5 & 12,43 & 10 \\
\hline Girl & 10 & 31,08 & 2,2 & 12,52 & 16 \\
\hline Total & 23 & 31,20 & 1,8 & 12,48 & 13 \\
\hline
\end{tabular}

\section{DISCUSSION}

This study investigated of physical activity students attain during traditional elementary physical education classes. It was found that students, not reaching the recommended intensity level at doing physical activity. This result is not different with another study that displayed MVPA under 50\% [20] and another study that investigated the regular PE classes [21]. The length of the lesson is about 40 minutes and student spent 12,48 minutes in MVPA from total 40 minutes and data show that boys better in MVPA than girl. This result is not different with another study that describes boys are more active gender [22]. However, the limited sample may not cover the accurate data and the gap between boys and girl not different significantly. 
The study shows that the total MVPA at PE classes not reaching remonded intensity level. From observation to the teacher about material at PE classes, the teacher state that grade 3 elementary school students have not been required to doing physical activities that are too heavy. This situation situation may influence the results. However, this study can be an initial description of student physical activity during PE learning as a teacher evaluation material in the future.

\section{CONCLUSION}

The level of physical activity during physical education classes at 3rd grade elementary school is not reaching recommended intensity of physical activity $(31,20 \%)$ or students totally engaged active learning time under $50 \%$ MVPA.

\section{ACKNOWLEDGMENT}

The authors would like to thank the participants who gave their time to the study. We would also like to thank the schools who helped facilitate the research. Lastly, thanks to LPPM UPI for the funding.

\section{REFERENCES}

[1] R.K. Dasar, Laporan Hasil Riset Kesehatan Dasar (Riskesdas) Nasional, Jakarta: Badan Litbangkes, Depkes RI, 2007.

[2] J.F. Sallis, T.L. McKenzie, "Physical education's role in public health," Research quarterly for exercise and sport, vol. 62(2), 124-37, 1991.

[3] W.B. Strong, R.M. Malina, C.J. Blimkie, S.R. Daniels, R.K. Dishman, B. Gutin, A.C. Hergenroeder, A. Must, P.A. Nixon, J.M. Pivarnik, and T. Rowland, "Evidence based physical activity for school-age youth," The Journal of pediatrics, vol. 146(6), pp. 732-7. 2005.

[4] M. Costa, E. Coy, A. Gómez Conesa, "Educación para la salud. una estrategia para cambiar los estilos de vida. Fisioterapia, vol. 23(3), pp. 160, 2001.

[5] S. Aznar Laín, and T. Webster, "Actividad física y salud en la infancia y la adolescencia. Guía para todas las personas que participan en su educación," Madrid: Ministerio de Educación y Ciencia, 2009.

[6] World Health Organization. A guide for population-based approaches to increasing levels of physical activity: implementation of the WHO global strategy on diet, physical activity and health, 2007.

[7] Kemenkes, "Rekomendasi aktifitas fisik bagi remaja," [Internet], 2019.

[8] J.F. Sallis, and K. Patrick, "Physical activity guidelines for adolescents: consensus statement. Pediatric exercise science, vol. 6(4), pp. 302-14, 1994.
[9] G. Baquet, S. Berthoin, and E.V. Praagh, "Are intensified physical education sessions able to elicit heart rate at a sufficient level to promote aerobic fitness in adolescents?," Research Quarterly for Exercise and Sport, vol. 73(3), pp. 282-8, 2002

[10] D.A. Dudley, A.D. Okely, W.G. Cotton, P. Pearson, and P. Caputi, "Physical activity levels and movement skill instruction in secondary school physical education," Journal of Science and Medicine in Sport, vol. 15(3), pp. 231-7, 2012.

[11] A. Marques, N, Ferro, J. Diniz, F.C. da Costa, "Health-related fitness in physical education- 45 versus 90 minutes classes," Br J Sports Med, vol. 45(15), pp. A11, 2011.

[12] C.A. Howe, P.S. Freedson, S. Alhassan, H.A. Feldman, and S.K. Osganian, "A recess intervention to promote moderate-to-vigorous physical activity,” Pediatric Obesity, vol. 7(1), pp. 82-8, 2012.

[13] K.R. Laurson, D.D. Brown, K.K. Dennis, and R.W. Cullen, "Heart rates of high school physical education students during team sports, individual sports, and fitness activities," Research Quarterly for Exercise and Sport, vol. 79(1), pp. 85-91, 2008.

[14] J.S. Duncan, H.M. Badland, and G. Schofield, "Combining GPS with heart rate monitoring to measure physical activity in children: A feasibility study," Journal of Science and Medicine in Sport. Vol. 12(5), pp. 583-5, 2009.

[15] J. Luis, and Y. Lucas,"original intensity of physical education classes in adolescents, 2015.

[16] J.B. Adams, "High School Physical Education Students' Heart Rates during different activities," Journal of Physical Education, Recreation and Dance, vol. 80(9), pp. 8, 2009.

[17] Z. Gao, J.C. Hanno, and R.L. Carson, "Middle schools students' heart rates during different curricular activities in physical education," International Council of Health, Physical Education, Recreation, Sport and Dance Journal of Research, vol. 4(1), pp. 16-19, 2009.

[18] B. Vandorpe, J. Vandendriessche, R. Vaeyens, J. Pion, S. Matthys, J. Lefevre, and M. Lenoir, "Relationship between sports participation and the level of motor coordination in childhood: A longitudinal approach," Journal of Science and Medicine in Sport, vol. 15(3), pp. 220-225, 2012.

[19] Gabbard, C, "Lifelong motor development (6th ed.)," San Francisco, CA: Benjamin Cummings. Gallahue, 2011.

[20] M. Kirkham-King, T.A. Brusseau, J.C. Hannon, D.M. Castelli, K. Hilton, and R.D. Burns,"Elementary physical education: A focus on fitness activities and smaller class sizes are associated with higher levels of physical activity," Prev Med Reports [Internet], vol. 8, pp. 135-9, 2017.

[21] S.J. Fairclough, and G. Stratton, "A review of physical activity levels during elementary school physical education," J Teach Phys Educ, vol. 25(2), pp. 239-57, 2006.

[22] E.L. Deci, and R.M. Ryan, "Intrinsic motivation and self-determination in human behavior," New York: Plenum Press, 1985. 